\title{
Measuring Tuberculosis related stigma and its determinants in Egypt: A community based study
}

\author{
Gadallah M *, Mokhtar A **, El-Moghazy E ** , Fawzy M **, Baker A **, Rady M * \\ * Community Medicine Department.-Faculty of Medicine, Ain Shams University - Egypt \\ ** Ministry of Health and Population, National Tuberculosis Program - Egypt \\ Received February $2016 \quad$ Accepted May 2016
}

\begin{abstract}
Background: Tuberculosis is still an important public health problem in Egypt. The condition is highly stigmatised, with considerable discrimination towards sufferers. The objectives of our research were therefore to take the first steps towards determining the magnitude and determinants of stigma associated with TB. Methods: A multistage stratified cluster random sample was employed in this house to house survey which targeted adult males and females from 15-65 years old in 6 randomly selected governorates. An interview questionnaire covering 5 sections of questions about socio-demographics, tuberculosis knowledge, attitude, stigma and gender discrimination was used. Fifteen indicators of stigma were used and a stigma index was calculated. Results: The prevalence of stigma among the studied sample was below the average $=44.9 \%$. The significant predictors were the presence of gender discrimination, level of participant's knowledge and attitude towards TB, gender, residency and having a job or not as depicted from logistic regression analysis. Conclusion: Females, jobless population and rural residents are the most important target groups for health education programs.
\end{abstract}

Key word: tuberculosis, stigma, prevalence, gender discrimination.

Corresponding and reprint requests: Mohsen Gadallah;

Email : mohsengadallah@gmail.com Or mohsengadallah@med.asu.edu.eg

\section{Introduction}

Stigma is a process that begins when a particular trait or characteristic of an individual or group is identified as being undesirable or disvalued ${ }^{(1)}$. Stigma related to chronic health conditions such as HIV/AIDS, leprosy, tuberculosis (TB), mental illness and epilepsy is a global phenomenon with a severe impact on individuals and their families, and on the effectiveness of public health programs (2).

In Egypt the estimates of the TB burden in 2012 according to WHO were $0.46,29$ and 17 for the mortality, prevalence and incidence rates per 100,000 populations $^{(3)}$.

Considerable geographic variability exists in the perceived prevalence of TB stigma, with $27 \%$ to $80 \%$ of at-risk individuals reporting that $\mathrm{TB}$ is stigmatized in their communities ${ }^{(4-6)}$. TB stigma is felt more strongly in certain subpopulations, including women, refugees, individuals from rural areas, and people with lower education levels ${ }^{\text {(7- }}$ 9).

The socioeconomic consequences of TB stigma differ in men and women. In 
general, men are more concerned with the impact of TB stigma on their economic prospects, which include job loss and reduced income ${ }^{(10-12)}$. While TB stigma also affects their financial status, women tend to be more concerned that TB stigma will adversely impact their marriage prospects or that their families will shun them ${ }^{(12-13)}$.

Although there is geographic and cultural variation in the explanations for why TB is stigmatized, most authors identify the perceived contagiousness of $\mathrm{TB}$ as a leading cause of stigmatization (14-16). Lack of knowledge regarding routes of TB transmission may also contribute to TB stigma ${ }^{(17)}$.

Although there have been several studies assessing the extent of such discrimination, there is no published research explicitly investigating stigma among the general Egyptian population. This study aimed to measure the magnitude of TB-related stigma in Egypt, its locally relevant features and its sociocultural determinants

\section{SUBJECTS \& METHODS}

This study is based on secondary analysis of data collected from a survey titled " Knowledge, Attitudes and Practices of Tuberculosis in Egypt: CommunityBased Study" carried out by the National TB Control Program (NTP), Ministry of Health and Population Egypt in conjunction with the WHO/EMRO office in 2008 and funded by the Global Fund .

Study population: The original house to house survey was targeting both urban and rural men and women aged 15-65 years. The study included respondents in the age group from 15 to 65 years, of any sex and who were willing to participate and to give written consent. People with a prior history of TB were excluded to avoid selection bias.

\section{Sampling:}

A multistage stratified cluster random sampling design was employed in this study. The sampling frame was constructed in three stages. Egypt is divided into 27 governorates. Taking into consideration the geographical distribution of the governorates, 6 governorates were selected randomly (as stratum 1) which are: Cairo, Alexandria, Gharbayia, Ismailyia, Menia, and Aswan. At each governorate, we used the 30 districts classification previously determined by WHO in vaccination coverage surveys to select 10 districts randomly as stratum 2 . This classification takes in its consideration the representation of both urban and rural areas or urban and semi-urban areas in each governorate. One block from each district was selected randomly (third stratum). From each block around 138 households were selected systemically from a list of households.

Sample size: As, there was no published information about the prevalence of TB stigma among the Egyptians, we assumed the prevalence to be $50 \%$ to give the maximum sample size. With a confidence interval $=95 \%$, test power $=80 \%$, margin of error $=5 \%$, and a maximum variance inflation factor of 3 due to the expected geographic heterogeneity and behavior in rural and urban areas of the identified stratum, 1152 participants were required from each governorate. This number was inflated by $20 \%$ to 1383 for the expected non response. Accordingly, the minimum required total sample was $=1383 \times 6=8298$ participants. 
Study tool: The survey instrument was a structured interview questionnaire using the respondent's own language or dialect. The questionnaire and methodology were pre-tested thoroughly and extensively before use. A full one day training course was conducted for the data collectors. Then, the final format in Arabic language was formulated.

The tool was a closed end questionnaire covering 5 sections of questions. These are: personal \& socioeconomics (12 quests), knowledge and source of TB information (58 quests), attitude (12 quests), stigma (15 quests) and gender discrimination (4 quests).

Assessment of Stigma: Fifteen indicators of stigma were included in the interview, based on experience from previous similar studies at developing countries ${ }^{(14,18)}$. These indicators included aspects of disclosure of the disease, shame, social isolation, relations with others and marriage. Responses to these questions were coded and assigning values of (2) for full agreement, (1) for uncertain and (0) for no agreement. Questions about different aspects of stigma were analyzed individually, and an index was assessed for internal consistency with the Cronbach's alpha statistic. This index was categorized by using its median score $(=1)$ into: +ve stigma if the index value was above the median and -ve stigma if it was equal to or below the median.

Assessment of the Knowledge, attitude and gender discrimination:

- The knowledge about TB was assessed using yes/no/don't know response format (Cronbach's alpha= 0.82). Each correct response was given a score of (1) and the wrong one or don't know was given a score of (0) giving a total sum score ranged from 0-58 points. On assessment, a median score $(=19)$ was used to divide the knowledge into "Poor" knowledge if the total score $\leq 19$ and "Good" for scores above 19 .

- The attitude was assessed using 5 Likert scale responses ranged from strong agree to strong disagree (Cronbach's alpha = 0.80). To ease the analysis, both the strong agree and agree was summed as one category and the strong disagree and disagree as one category also. Each positive attitude was given a score of (2), no opinion was given a score of (1) and negative attitude was given a score of (0) giving a total sum score ranged from 0-24 points. On assessment, a median score $(=17)$ was used to divide the attitude into "Bad" attitude (total score was $\leq 17$ ) and "Good" attitude (total score > 17).

- Gender discrimination was examined using 3 likert scale response (strong agree/ agree/ disagree) for 4 negative statements (Cronbach's alpha $=\mathbf{0 . 7 6}$ ). Strongly agree was given a score of (2), agree was given a score of (1) while disagree was given a score of (0). The total sum score ranged from $0-8$ points. On assessment, a median score $(=6)$ was used to divide the discrimination into 2 levels; "+ve" gender discrimination if the total score was above the median and "ve" discrimination for score equal to or below the median.

Data Analysis: Collected data were analyzed using the Statistical Package for Social Science (SPSS) program version 20.0 (SPSS Inc., Chicago, IL, USA). Frequencies, percentages, mean and median were used for descriptive analysis. Spearman correlation " $r$ " coefficient was used to correlate between stigma indicators and the stigma index. Chi-square analyses were used to 
compare categorical variables. The odds ratio (OR) with the $95 \% \mathrm{CI}$ was calculated. Logistic regression analysis model was used to identify the significant predictors for the presence of stigma and the adjusted ORs were also calculated. All through the statistical analyses, a $P$ value of $<0.05$ was considered statistically significant.

Ethical Consideration: The survey was approved by the health authorities both central and at governmental level. Informed consent was obtained from all the study participants after describing to them all the issues related to the study in details. Data were kept anonymous and all efforts were made to maintain confidentiality related to the information provided and recorded in the dataset. The study protocol was approved by the Ethical Committee of the Faculty of Medicine, Ain Shams University.

Financial Support: The original study Knowledge, Attitudes and Practices of Tuberculosis in Egypt: CommunityBased Study" received technical and financial support from WHO/EMRO and the Global Fund.

\section{Results}

Eight thousands and three hundreds and three (8303) participants have been interviewed in this survey. Male to female ratio was 0.9. Their mean age was $36.5(\mathrm{SD}=2.7)$ ranging between 15 and 65 years old. One third $(34.0 \%)$ of the studied sample were illiterate or just able to read and write and about $40 \%$ achieved secondary or institutional education (2 years after secondary education). $56.1 \%$ were urban residents. Almost three forth of the sample $(73.0 \%)$ were married and $52 \%$ of them have on the average 3 to 4 children. $40 \%$ of them do not work and $22.1 \%$ were employees. About two third of them own their household (63.7\%) and the average household members is nearly 5 (Table 1).

The mean $( \pm$ SD) stigma index was $0.99 \pm$ 0.32 and the median equals to 1 . The internal consistency of the item-adjusted index was good (Cronbach's alpha 0.78). All individual items to total index correlations were highly significant (Table 2).

The prevalence of stigma among the studied sample was below the average $=$ 44.9\%. Participants who were females, above 35 years old, with lower educational level (<secondary school), the married, those did not own their houses, residents of rural areas, those had poor knowledge and bad attitude toward TB and those showing gender discrimination had significantly higher stigma than the comparative categories as shown in table 3. However the home crowdedness was not associated with presence of stigma.

To identify the significant predictors for stigma from among all the significant associated independents variables, adjusted for confounding, logistic regression analysis was performed. In order to avoid co-linearity the educational level was excluded from the model as it was found to be highly correlated with both the knowledge and attitude levels ( $\mathrm{r}=\mathrm{O} .85,0.82$ respectively). The significant predictors were the level of participant's knowledge and attitude towards TB, presence of gender discrimination, gender, residency and having a job (Table 3 ).

\section{Discussion}


Opposite of other studies, where TB patients ${ }^{(19-21)}$ or health care workers ${ }^{(22,23)}$ were mostly included, we focused our research on the general population to identified features of TB-related stigma among representative sample of the Egyptian population.

In this study participants affirmed the stigma indicators "TB affects relation with friends, colleagues and relatives" among the most important features of stigma, highlighting a fundamental feature of stigma based on personal and social distress and recalling Goffman's original formulation of stigma as 'disqualification from full social acceptance' (1). These findings highlight also persisting widespread fear of the disease, lack of information about TB and its treatment and the expected dearth of support which TB patients can face in our community. Three quarters of the participants of the study supported that stigma indicator "Tuberculosis affects ability to work" was the most important one to them. This may be due to the deep seated idea that TB is always associated with physical disability with subsequent loss of job and income and further complicating the expense of treatment.

Patients often isolate themselves to avoid infecting others and to avoid uncomfortable situations such as being ignored. Our study provides a support for this perception as more than half of them demonstrated their preference to live isolated in case of having TB. However, the international strategy for TB control published by Stop TB Partnership and World Health Organization has until its Global Plan to Stop TB 2006-2015(24) treated TB as a biomedical rather than a social disease, showed little awareness of the need for patient-centered approaches and there is no mention of stigma and discrimination associated with $\mathrm{TB}$, even though publications by the WHO repeatedly acknowledge that $\mathrm{TB}$ is a highly stigmatized disease ${ }^{(25)}$.

The present study documents the significant difference in prevalence of stigma between males and females, similar to several other studies (10-13) which suggest a psychosocial burden of TB-related stigma among women and a financial and work-related effect among men. However, specific gender effects of TB related stigma require further study, considering the role of gender and its impact on this problem.

The possible explanations for the association between the stigma and the lower level of knowledge about TB among the study participants may be due to the low educational level of them since $46.6 \%$ did not reach the secondary school education or that non diseased population received less $\mathrm{TB}$-specific education or retained less information from TBspecific education because they were not ill. So, we found that disease-specific knowledge may need to be improved among the whole population not just among the diseased patients. More educated people would be less ashamed if sick in comparison to the less educated respondents. This is not a surprising finding since a higher TB knowledge score has been associated with higher education level after excluding other demographic or socioeconomic factors as shown in other researches $(21,23,26)$. Increasing knowledge is one of the approaches in stigma-reduction activities (27). This is in line with new WHO Stop TB strategy in which Advocacy, Communication and Social Mobilization (ACSM) are essential activities in our struggle against $\mathrm{TB}^{(28)}$. 
The association between stigma and the bad attitude towards TB among the study participants reflects the combined cultural concepts of TB and misperceived risk from exaggerated concerns about spread of the disease. A significant proportion of the study respondents would be uncomfortable being near to TB patients and they would avoid physical contact such as touching and handshaking. This is in accordance with other similar studies ${ }^{(13,19,20,29)}$. All these studies were unanimous that a community's perception of TB strongly influences the attitudes towards TB patients which in turn influence patient's health seeking behavior. They added also the importance of addressing community perceptions of $\mathrm{TB}$, rather than simply individual patient or family members' attitudes.

The high association between gender discrimination in our society and stigma may be due to the fact that Egypt is one of the male dominated societies like most of the developing countries.

The multiple causes of stigma phenomenon will require multiple interventions tailored to the local context and social system. Without knowledge of the causes of stigma and discrimination associated with TB in our community, it is difficult to devise discriminationreduction strategies that are likely to work. There is therefore a need to investigate the causes of discrimination in depth and from patients families' and health care workers' perspectives.

\section{Conclusion}

TB related stigma is slightly below the average among the Egyptian population. The levels of knowledge, attitude and gender discrimination are the most important determinants of this stigma. Females, jobless population and rural residents are the most important target groups for health education programs.

Conflict of Interest: No conflict of interest is declared

\section{References}

1) Courtwright $\mathrm{A}$, and Turner AN. Tuberculosis and Stigmatization: Pathways and Interventions. Public Health Rep. 2010; 125(4): 34-42.

2. Van Brakle, W H. Measuring healthrelated stigma-A literature review. Psychology, Health \& Medicine. August 2006;11(3):307-334

3) WHO. Tuberculosis-Egypt 2012. Available from:

http://www.emro.who.int/egy/programm es/tuberculosis.html

4) Qureshi SA, Morkve O, Mustafa T. Patient and health system delays: healthcare seeking behaviour among pulmonary tuberculosis patients in Pakistan. J Pak Med Assoc 2008;58:31821.

5) Ali SS, Rabbani F, Siddiqui UN, Zaidi AH, Sophie A, Virani SJ, et al. Tuberculosis: do we know enough? A study of patients and their families in an out-patient hospital setting in Karachi, Pakistan. Int $\mathrm{J}$ Tuberc Lung Dis 2003;7:1052-8.

6) Ottmani S, Obermeyer Z, Bencheikh N, Mahjour J. Knowledge, attitudes and beliefs about tuberculosis in urban 
Morocco. East Mediterr Health J 2008;14:298-304.

7) Eastwood SV, Hill PC. A genderfocused qualitative study of barriers to accessing tuberculosis treatment in The Gambia, West Africa. Int J Tuberc Lung Dis 2004;8:70-5.

8) Panic E, Panic I. Some epidemiological and socio-medical peculiarities of pulmonary tuberculosis (pTB) among individuals from war affected areas (WAA) - experiences and results from north-west Yugoslavia (NWYU). Pneumologia 2003;52:93-8.

9) Berisha M, Zheki V, Zadzhmi D, Gashi S, Hokha R, Begoli I. Level of knowledge regarding tuberculosis and stigma among patients suffering from tuberculosis. Georgian Med News 2009;166:89-93.

10) Long NH, Johansson E, Diwan VK, Winkvist A. Fear and social isolation as consequences of tuberculosis in VietNam: a gender analysis. Health Policy 2001;58:69-81.

11) Atre SR, Kudale AM, Morankar SN, Rangan SG, Weiss MG. Cultural concepts of tuberculosis and gender among the general population without tuberculosis in rural Maharashtra, India. Trop Med Int Health 2004;9:1228-38.

12) Ganapathy S, Thomas BE, Jawahar MS, Selvi KJ, Sivasubramaniam, Weiss M. Perceptions of gender and tuberculosis in a south Indian urban community. Indian J Tuberc 2008;55:914.

13) Zhang T, Liu X, Bromley H, Tang S. Perceptions of tuberculosis and health seeking behaviour in rural Inner Mongolia, China. Health Policy 2007;81:155-65.

14) Dodor EA, Kelly S. "We are afraid of them": attitudes and behaviours of community members towards tuberculosis in Ghana and implications for TB control efforts. Psychol Health Med 2009;14:170-9.

15) Sharma N, Malhotra R, Taneja DK, Saha R, Ingle GK. Awareness and perception about tuberculosis in the general population of Delhi. Asia Pac J Public Health 2007;19:10-5.

16) Macq J, Solis A, Martinez G, Martiny P, Dujardin B. An exploration of the social stigma of tuberculosis in five "municipios" of Nicaragua to reflect on local interventions. Health Policy 2005;74:205-17.

17) West EL, Gadkowski LB, Ostbye T, Piedrahita C, Stout JE. Tuberculosis knowledge, attitudes, and beliefs among North Carolinians at increased risk of infection. N C Med J 2008;69:14-20.

18) Liefooghe R, Baliddawa J B, Kipruto E M, Vermeire C, De Munynck A O. From their own perspective. A Kenyan community's perception of tuberculosis. Trop Med Int Health 1997; 2: 809-821.

19) Jittimanee SX, Nateniyom $S$, Kittikraisak W, Burapat C, Akksilp S, Chumpathat N, et al. Social stigma and knowledge of tuberculosis and HIV among patients with both diseases in Thailand. PLoS One 2009;4:e6360.

20) Van RA, Sengupta $S$, Pungrassami $P$, Balthip Q, Choonuan S, Kasetjroen Y, et 
al. Measuring stigma associated with tuberculosis and HIV/AIDS in southern Thailand: exploratory and confirmatory factor analyses of two new scales. Top Med Int Health 2008; 13:21-30.

21) Khan, J. A., Irfan, M., Zaki, A., Beg, M., Hussain, S. F., Rizvi, N. Knowledge, attitude and misconceptions regarding tuberculosis in Pakistani patients. J Pak Med Assoc 2006 May; 56 (5): 211-4.

22) Macq J, Solis A, Martinez G. Assessing the stigma of tuberculosis. Psychol Health Med 2006;11:346-52.

23) Wu PS, Chou P, Chang NT, Sun WJ, Kuo HS. Assessment of changes in knowledge and stigmatization following tuberculosis training workshops in Taiwan. J Formos Med Assoc 2009;108:377-85.

24) Stop TB Partnership and World Health Organization. Global Plan to Stop TB 2006-2015. 2006. Geneva. Available from:

http://www.stoptb.org/assets/documents/ global/plan/TB_GlobalPlanToStopTB20 11-2015.pdf

25) World Health Organisation: Global Tuberculosis Control: surveillance, planning, financing. WHO report 2006.
Geneva: World Health Organisation; 2006.

26) Jurce-Savicevic A, Popovic-Grle $S$, Milo-Vac S, Ivcevic I, Vukasovic M, Viali V, Zivk-Ovic K. Tuberculosis Knowledge among patients in outpatient settings in Split Croatia. Int $\mathbf{J}$ Tuberc Lung Dis 2008; 12:780-12.

27) Heijnders M, Van der Meij S. The fight against stigma: an overview of stigma-reduction strategies and interventions. Psychol Health Med 2006;11:353-63.

28) WHO. Advocacy, Communication and Social mobilization (ACSM) for tuberculosis control: a handbook for country programmes. World Health Organization 2007. Available from:

http://www.stoptb.org/assets/documents/resour ces/publications/acsm/ACSM Handbook.pdf

29) Cramm JM, Finkenflugel HJ, Moller $\mathrm{V}$, Niebore AP. TB treatment initiation and adherence in a South African community influenced more by perceptions than by knowledge of tuberculosis. BMC Public Health 2010; 108:377-85. 
Table (1): Personal \& socio-demographic characteristics of the studied sample $(\mathbf{n}=\mathbf{8 3 0 3})$

\begin{tabular}{|c|c|}
\hline Variables & \\
\hline Age in years: Mean \pm SD, range & $36.5 \pm 2.7,15-65$ \\
\hline $\begin{array}{l}\text { Gender: N (\%) } \\
\text { - Females }\end{array}$ & $4363(52.5)$ \\
\hline $\begin{array}{l}\text { Education Level: } \mathrm{N}(\%) \\
\text { - Illiterate and Read and Write } \\
\text { - Primary and Preparatory } \\
\text { - Secondary and Institutional } \\
\text { - University and Post Graduates }\end{array}$ & $\begin{array}{l}2820(34.0) \\
1049(12.6) \\
3348(40.3) \\
1086(13.1)\end{array}$ \\
\hline $\begin{array}{l}\text { Residence: N (\%) } \\
\text { - Urban }\end{array}$ & $4662(56.1)$ \\
\hline $\begin{array}{l}\text { Marital status: N (\%) } \\
\text { - Single } \\
\text { - Divorced } \\
\text { - Widowed } \\
\text { - Married }\end{array}$ & $\begin{array}{r}1770(21.3) \\
98(1.20) \\
374(4.50) \\
6061(73.0) \\
\end{array}$ \\
\hline \begin{tabular}{|c|} 
Occupation: $\mathrm{N}(\%)$ \\
- Work: Farmer \\
Worker \\
Employee \\
Private business \\
Others \\
- Don't work \\
\end{tabular} & $\begin{array}{r}720(8.70) \\
901(10.9) \\
1839(22.1) \\
912(11.0) \\
607(7.30) \\
3324(40.0) \\
\end{array}$ \\
\hline $\begin{array}{l}\text { Number of Household members } \\
\text { Mean (SD), } 95 \% \text { CI } \\
\end{array}$ & $4.9(2.1), 4.8-4.9$ \\
\hline $\begin{array}{l}\text { Number of Rooms in Household } \\
\text { Mean (SD), 95\% CI }\end{array}$ & $2.9(1.2), 2.9-3.0$ \\
\hline $\begin{array}{l}\text { State of Household Ownership: N (\%) } \\
\text { - Owned } \\
\text { - Rented } \\
\text { - no special accommodation } \\
\end{array}$ & $\begin{array}{rr}5293 & (63.7) \\
2771 & (33.4) \\
239 & (2.90) \\
\end{array}$ \\
\hline
\end{tabular}


Table (2): Indicators of tuberculosis-related stigma and its correlation to Stigma Index among the studied sample $(\mathrm{n}=\mathbf{8 3 0 3})$.

\begin{tabular}{|l|l|l|}
\hline Indicator & Mean \pm SD & "r" \\
\hline 1- Shamed or embarrassed if tuberculosis & $1.10 \pm 0.93$ & 0.57 \\
\hline 2-Desire to keep others from knowing & $0.58 \pm 0.84$ & 0.43 \\
\hline 3-Tuberculosis affects ability to work & $1.69 \pm 0.60$ & 0.71 \\
\hline 4-TB affects relation with friends & $1.49 \pm 0.75$ & 0.68 \\
\hline $\begin{array}{l}\text { 5-Tuberculosis affects relationship with } \\
\text { colleagues }\end{array}$ & $1.52 \pm 0.72$ & 0.69 \\
\hline $\begin{array}{l}\text { 6-Tuberculosis affects relationship with } \\
\text { relatives }\end{array}$ & $1.40 \pm 0.81$ & 0.65 \\
\hline 7-Tuberculosis affects marital relationship & $1.34 \pm 0.78$ & 0.59 \\
\hline 8-Prefer to live isolated in case of having TB & $1.45 \pm 0.56$ & 0.54 \\
\hline $\begin{array}{l}\text { 9-Problem with future daughter husband if } \\
\text { tuberculosis }\end{array}$ & $1.45 \pm 0.55$ & 0.41 \\
\hline $\begin{array}{l}\text { 10-Problem with future wife of one of the } \\
\text { family members if tuberculosis }\end{array}$ & $1.45 \pm 0.56$ & 0.41 \\
\hline $\begin{array}{l}\text { 11-Avoidance \& stay away of tuberculosis } \\
\text { colleague in job }\end{array}$ & $0.47 \pm 0.72$ & 0.24 \\
\hline $\begin{array}{l}\text { 12-Agreement of contact screening if one is } \\
\text { put in the same situation of a tuberculosis } \\
\text { colleagues }\end{array}$ & $0.28 \pm 0.58$ & 0.13 \\
\hline $\begin{array}{l}\text { 13-Avoidance \& stay away of tuberculosis } \\
\text { family member }\end{array}$ & $0.43 \pm 0.75$ & 0.16 \\
\hline $\begin{array}{l}\text { 14-Agreement of other family members } \\
\text { screening if one is put in the same situation } \\
\text { of a tuberculosis family member }\end{array}$ & $0.25 \pm 0.55$ & 0.13 \\
\hline $\begin{array}{l}\text { 15-Spouses should be separated if one is } \\
\text { tuberculosis }\end{array}$ & $0.46 \pm 0.71$ & 0.35 \\
\hline Stigma Index & $0.99 \pm 0.32$ & 1 \\
\hline Cronbach's alpha =0.78 & & \\
\hline
\end{tabular}


Table (3): Prevalence of stigma and its distribution among the studied independent variables

\begin{tabular}{|c|c|c|c|c|c|}
\hline $\begin{array}{l}\text { Independent } \\
\text { variables: }\end{array}$ & No. $(\%)$ & stigma \% & $\begin{array}{l}X^{2} \\
(p)\end{array}$ & $\begin{array}{l}\text { Crude OR } \\
\text { (95\% CI) }\end{array}$ & $\begin{array}{l}\text { Adjusted OR } \\
(95 \% \text { CI })\end{array}$ \\
\hline $\begin{array}{l}\text { Sex: } \\
\text { Female } \\
\text { Male }\end{array}$ & $\begin{array}{l}4364(52.5) \\
3940(47.5)\end{array}$ & $\begin{array}{l}53.8 \\
47.2\end{array}$ & $\begin{array}{l}8.71 \\
\mathbf{0 . 0 0 3}\end{array}$ & $\begin{array}{l}1.3(1.09-1.56) \\
1\end{array}$ & $\mathbf{1 . 5 5}(1.25-1.87)$ \\
\hline $\begin{array}{l}\text { Age: } \\
\text { >Median (>35ys) } \\
\text { <=Median (<=35ys) }\end{array}$ & $\begin{array}{l}4089(49.2) \\
4214(50.8)\end{array}$ & $\begin{array}{l}49.0 \\
43.3\end{array}$ & $\begin{array}{c}6.54 \\
\mathbf{0 . 0 1}\end{array}$ & $\begin{array}{l}1.26(1.07-1.51) \\
1\end{array}$ & $1.09(0.74-1.28)$ \\
\hline $\begin{array}{l}\text { Education: } \\
\text { <Secondary school } \\
\text { Secondary \& above } \\
\end{array}$ & $\begin{array}{l}3869(46.6) \\
4434(53.4)\end{array}$ & $\begin{array}{l}53.6 \\
47.7 \\
\end{array}$ & $\begin{array}{l}6.96 \\
\mathbf{0 . 0 0 8}\end{array}$ & $\begin{array}{l}1.27(1.06-1.52) \\
1\end{array}$ & $\mathrm{ND}^{*}$ \\
\hline $\begin{array}{l}\text { Marital Status: } \\
\text { Married } \\
\text { Single/Divorced/Widow }\end{array}$ & $\begin{array}{l}6061(73.0) \\
2242(27.0)\end{array}$ & $\begin{array}{l}52.2 \\
47.2\end{array}$ & $\begin{array}{l}5.00 \\
\mathbf{0 . 0 2 5}\end{array}$ & $\begin{array}{l}1.22(1.04-1.49) \\
1\end{array}$ & $0.93(0.82-1.05)$ \\
\hline $\begin{array}{l}\text { House: } \\
\text { Rent/others } \\
\text { Owner }\end{array}$ & $\begin{array}{l}5532(66.6) \\
2771(33.4)\end{array}$ & $\begin{array}{l}50.9 \\
45.4\end{array}$ & $\begin{array}{l}6.06 \\
\mathbf{0 . 0 1 3}\end{array}$ & $\begin{array}{l}1.25(1.11-1.49) \\
1\end{array}$ & $0.96(0.89-1.10)$ \\
\hline $\begin{array}{l}\text { Residency: } \\
\text { Rural } \\
\text { Urban }\end{array}$ & $\begin{array}{l}3641(43.9) \\
4662(56.1)\end{array}$ & $\begin{array}{l}50.5 \\
45.7\end{array}$ & $\begin{array}{l}4.61 \\
\mathbf{0 . 0 3 1}\end{array}$ & $\begin{array}{l}1.21(1.09-1.45) \\
1\end{array}$ & $1.39(1.17-1.53)$ \\
\hline $\begin{array}{l}\text { Crowdedness Index: } \\
>3 \\
<=3\end{array}$ & $\begin{array}{l}1304(15.7) \\
6999(84.3)\end{array}$ & $\begin{array}{l}47.6 \\
47.0\end{array}$ & $\begin{array}{l}0.07 \\
0.788\end{array}$ & $\begin{array}{l}1.02(0.86-1.23) \\
1\end{array}$ & $1.04(0.84-1.28)$ \\
\hline $\begin{array}{l}\text { Job: } \\
\text { Jobless } \\
\text { Has a job }\end{array}$ & $\begin{array}{l}3324(40.0) \\
4979(60.0)\end{array}$ & $\begin{array}{l}52.8 \\
47.6\end{array}$ & $\begin{array}{l}5.41 \\
\mathbf{0 . 0 2}\end{array}$ & $\begin{array}{l}1.23(1.03-1.47) \\
1\end{array}$ & $\mathbf{1 . 4 4}(1.20-1.63)$ \\
\hline $\begin{array}{l}\text { Knowledge level: } \\
\text { Poor } \\
\text { Good }\end{array}$ & $\begin{array}{l}4425(53.3) \\
3878(46.7)\end{array}$ & $\begin{array}{l}60.1 \\
33.8\end{array}$ & $\begin{array}{l}138.85 \\
\mathbf{0 . 0 0 0}\end{array}$ & $\begin{array}{l}2.95(2.6-3.55) \\
1\end{array}$ & $\mathbf{2 . 6 7}(2.37-2.99)$ \\
\hline $\begin{array}{l}\text { Attitude Level: } \\
\text { Bad } \\
\text { Good }\end{array}$ & $\begin{array}{l}4736(57.0) \\
3567(43.0)\end{array}$ & $\begin{array}{l}59.0 \\
33.0\end{array}$ & $\begin{array}{l}136.07 \\
\mathbf{0 . 0 0 0}\end{array}$ & $\begin{array}{l}2.92(2.42-3.52) \\
1\end{array}$ & $\mathbf{2 . 4 6}(2.19-2.76)$ \\
\hline $\begin{array}{l}\text { Gender } \\
\text { discrimination: } \\
\text { Present } \\
\text { Absent }\end{array}$ & $\begin{array}{l}2731(32.9) \\
5572(67.1)\end{array}$ & $\begin{array}{l}55.0 \\
44.3\end{array}$ & $\begin{array}{l}22.90 \\
\mathbf{0 . 0 0 0}\end{array}$ & $\begin{array}{l}1.54(1.28-1.84) \\
1\end{array}$ & $\mathbf{2 . 2 0}(1.96-2.47)$ \\
\hline Total & $\begin{array}{l}8303 \\
(100.0)\end{array}$ & $44.9 \%$ & & & \\
\hline
\end{tabular}

* $\mathrm{ND}=$ Not included in the model due to co-linearity 